Boletín de la Sociedad Geológica Mexicana

VOLUMEN 61, NÚM. 1, 2009, P. 1-12

\title{
Roundness in quartz grains from inland and coastal dune sands, Altar Desert, Sonora, Mexico
}

\author{
Juan José Kasper-Zubillaga, ${ }^{1, *}$ \\ ${ }^{1}$ Instituto de Ciencias del Mar y Limnología, Unidad de Geología Marina y Ambiental, Circuito Exterior s/n Coyoacán, México, D.F., \\ 04510, Universidad Nacional Autónoma de México \\ *kasper@icmyl.unam.mx
}

\begin{abstract}
A roundness analysis of quartz grains ( $\mathrm{n}=54$ ) from dunes from San Luis Río Colorado (SLRC), El Pinacate (EP), Golfo de Santa Clara (GSC) and Puerto Peñasco (PP), Sonora, Mexico, was carried out in order to determine the provenance of quartz grains and their relationship to different quartz types (monocrystalline quartz with straight/undulose extinction, with inclusions and polycrystalline quartz of plutonic origin and with straight/undulose extinction). Aeolian transport and wind selectiveness produces fine-grained and moderately to well sorted sands in SLRC and EP dune sands whereas medium sand sizes and moderately well sorted sands are present at sites GSC and PP suggesting mixing of aeolian/marine processes that generate different grain sizes of different composition. Roundness of quartz grains at sites SLRC and EP suggests fluvial transport in the Colorado River Delta but also to long aeolian transport. Some quartz grains from the GSC and PP sites showed angular and rounded quartz due to a mix of aeolian/marine processes. Samples from sites SLRC and EP concentrate monocrystalline quartz with straight and undulose extinction derived from a near source sediment. Samples from sites GSC and PP are dominated by monocrystalline quartz with straight and undulose extinction derived from plutonic and low-rank metamorphic rocks. Polycrystalline quartz is derived from plutonic and low-rank metamorphic rocks. Correlations between Mz vs. SA/SR (grain-size, subangular/subrounded quartz), VA/A vs. MU (very angular/angular quartz, monocrystalline quartz with undulose extinction) and Mz vs. SA/SR (grain size, subangular/subrounded quartz) indicate that coarse-sized grains are subangular probably due to little abrasion and rounding of grain edges trough transport, the presence of monocrystalline quartz with undulose extiction probably derived from low-rank metamorphic sources and an increase of grain size in relation to the angularity of the grains.
\end{abstract}

Key words: Roundness, Dunes, Monocrystalline quartz, Polycrystalline quartz, Sonora, Mexico.

\section{Resumen}

Un análisis de redondez se realizó en granos de cuarzo ( $n=54)$ en dunas de San Luis Río Colorado(SLRC), El Pinacate(EP), Golfo de Santa Clara (GSC) y Puerto Peñasco(PP), Sonora, México para determinar la procedencia del cuarzo y la relación con diferentes tipos de cuarzo (monocristalino con extinción recta/ondulante, con inclusiones y policristalino de orígen plutónico y extincion rectal ondulante). El transporte eólico y selectividad del viento produce arena de grano fino moderadamente a bien clasificada en SLRCy EP mientras que para GSC y PP la arena es media y moderadamente clasificada lo cual indica mezcla de procesos eólicos/marinos que generan diferentes tamaños de grano. La redondez del cuarzo en SLRC y EP sugiere transporte fluvial del Delta del Río Colorado pero también transporte eólico prolongado. Algunos granos de cuarzo de los sitios GSC y PP son angulosos y redondeados debido a la mezcla de procesos eólicos y marinos.Las muestras de los sitios SLRC y EP concentran cuarzo monocristalino con extinción recta y ondulante derivado de fuentes cercanas. Las muestras de los sitios GSC y PP están dominadas por cuarzo monocristalino con extinción recta y ondulante derivado de rocas plutónicas y de bajo metamorfismo. El cuarzo policristalino se deriva de rocas plutónicas y metamórficas de bajo grado. Las correlaciones entre Mz vs. SA/SR (tamaño de grano, cuarzo subanguloso/subredondeado), VA/A 
vs. MU (cuarzo muy anguloso/ anguloso, Cuarzo monocristalino con extinción ondulante) y Mz vs. SA/SR (tamaño de grano, cuarzo subanguloso/subredondeado) indican que los granos de cuarzo gruesos son subangulosos posiblemente por poca abrasión por transporte, la presencia de cuarzo con extinción ondulante derivado de rocas metamórficas de bajo grado y un incremento del tamaño de grano en relación a la angulosidad de los granos.

Palabras clave: Redondez, Dunas, Cuarzo Monocristalino, Cuarzo Policristalino, Sonora, Mexico.

\section{Introduction}

Quartz is one of the most abundant minerals in igneous, metamorphic and sedimentary rocks that makes it useful for roundness and provenance analysis due to its relative durability and diverse varieties (Basu et al., 1975; Basu, 1985; Pettijohn et al., 1972; Shepard, 1973; KasperZubillaga et al., 2005). Roundness is defined as the ratio of radius of curvature at the corners of a solid to the radius of curvature of the maximum inscribed sphere (Wadell, 1932). Roundness is an attribute in quartz that can be used to infer transport and abrasion in different sedimentary environments (Folk, 1978; Sagga, 1993; Kasper-Zubillaga et al. 2005). For instance, in beach and dune environments there is an increase in rounded quartz grains from the beach towards the dune crest due to selective transport and abrasion associated with time and distance (Beal and Shepard, 1956; Shepard and Young, 1961; KasperZubillaga et al., 2005). The main purpose of this work is to concentrate our roundness study in quartz grains coming from dune systems near the coast and inland. This is to interpret the provenance of sand that compose coastal and inland dune systems based on the quartz characteristics and to see if there is a relationship between quartz roundness and monocrystalline quartz types (i.e. straight and undulose extinction quartz types, quartz with inclusions) probably linked to differences in quartz durability (Blatt and Christie, 1963; Harrell and Blatt, 1978).

\section{Study Area}

The study area is located in the state of Sonora, Nortwestern Mexico 31-32 $2^{\circ} 5^{\prime}$ and $113^{\circ} 85^{\prime}$ to $115^{\circ}$. Sampling sites are located in San Luis Río Colorado (SLRC), El Pinacate (EP), Golfo de Santa Clara (GSC) and Puerto Peñasco (PP) (Fig. 1). The climate in the altar Desert is dry with less than $10 \mathrm{~cm}$ of rainfall annually.

Onshore northwesterly, southwesterly, and southeasterly winds occur 20 to 40 percent of the time per month with average velocities between 2 to $6 \mathrm{~m} / \mathrm{s}$. Winds generate from 25 to $30 \%$ of annual potential sand transport (Blount and Lancaster, 1990).

Longshore currents in the coastal area of the northern Gulf of California are induced by tides, winds, density gradients and geostrophy (Lavin and Badan-Dangon, 1997;
Marinone and Lavin, 1997). Tides are of semidiurnal type (up to $\sim 10 \mathrm{~m}$ amplitude) that induce current velocities from 1.5 to $3 \mathrm{mseg}^{-1}$ (Thompson, 1968; Cupul, 1994).

The Colorado River water annual flow varies from 7.3$24.6 \times 10^{9} \mathrm{~m}^{3}$ with a mean of $20.3 \times 10^{9} \mathrm{~m}^{3}$. However, the water storage capacity in dams along the river is approximately 4 times the mean annual flow (Andrews, 1991). At present, no direct water flow to the Gulf of California is observed due to the water storage in the Morelos Dam, Mexico (Vandivere and Vorster, 1984). The Sonoyta River flows intermittently throughout the valley in the south and discharges into the Gulf of California. (Fig. 1)

The geology of the area comprises volcanic, sedimentary, metamorphic and plutonic rocks (Fig. 2).

In the studied area, desert and coastal dunes are of linear and crescentic types (Blount and Lancaster, 1990). According to Blount and Lancaster (1990) and KasperZubillaga et al. (2007) the desert dunes of the Altar Desert were primarily originated from the old and modern flood plain and in the delta of the Colorado River since middle Pleistocene time.

\section{Materials and Methods}

Fifty four dune sand samples were collected from the Altar Desert and the Golfo de Santa Clara and Puerto Peñasco areas. Samples were collected from the crest and slip face (flank) in longitudinal and crescent dunes of the desert and coastal area of the Altar Desert (Fig. 1). Sampling was carried out in october-november of 2002 (fall-winter season). Approximately $0.1 \mathrm{~g}$ of sample was used for grain size determination. Textural parameters like mean graphic size $=\mathrm{Mz}$; sorting $=\sigma$; skewness $=\mathrm{Ski}$; kurtosis $=\mathrm{K}_{\mathrm{G}}($ Folk, 1978) were determined using a Laser Particle Size Analyzer (Model Coulter LS230) (Fig. 3; Table 1). The Coulter Analyzer is used for grain size determinations of particle sizes between $-1.0 \phi$ to $14.6 \phi$.

In order to estimate the roundness, 100 quartz grains were point counted in fifty four thin sections using the visual chart by Powers (1953). Quartz grains were classified and counted as $\mathrm{VA}=$ very angular, $\mathrm{A}=$ angular, $\mathrm{SA}=$ subangular, $\mathrm{SR}=$ subrounded, $\mathrm{R}=$ rounded and $\mathrm{VR}=$ very rounded (Table 1). Then, roundness ratios VA/A (very angular/angular), SA/SR (subangular/ subrounded) and R/VR (rounded/very rounded) were determined to be used as poles in a ternary 


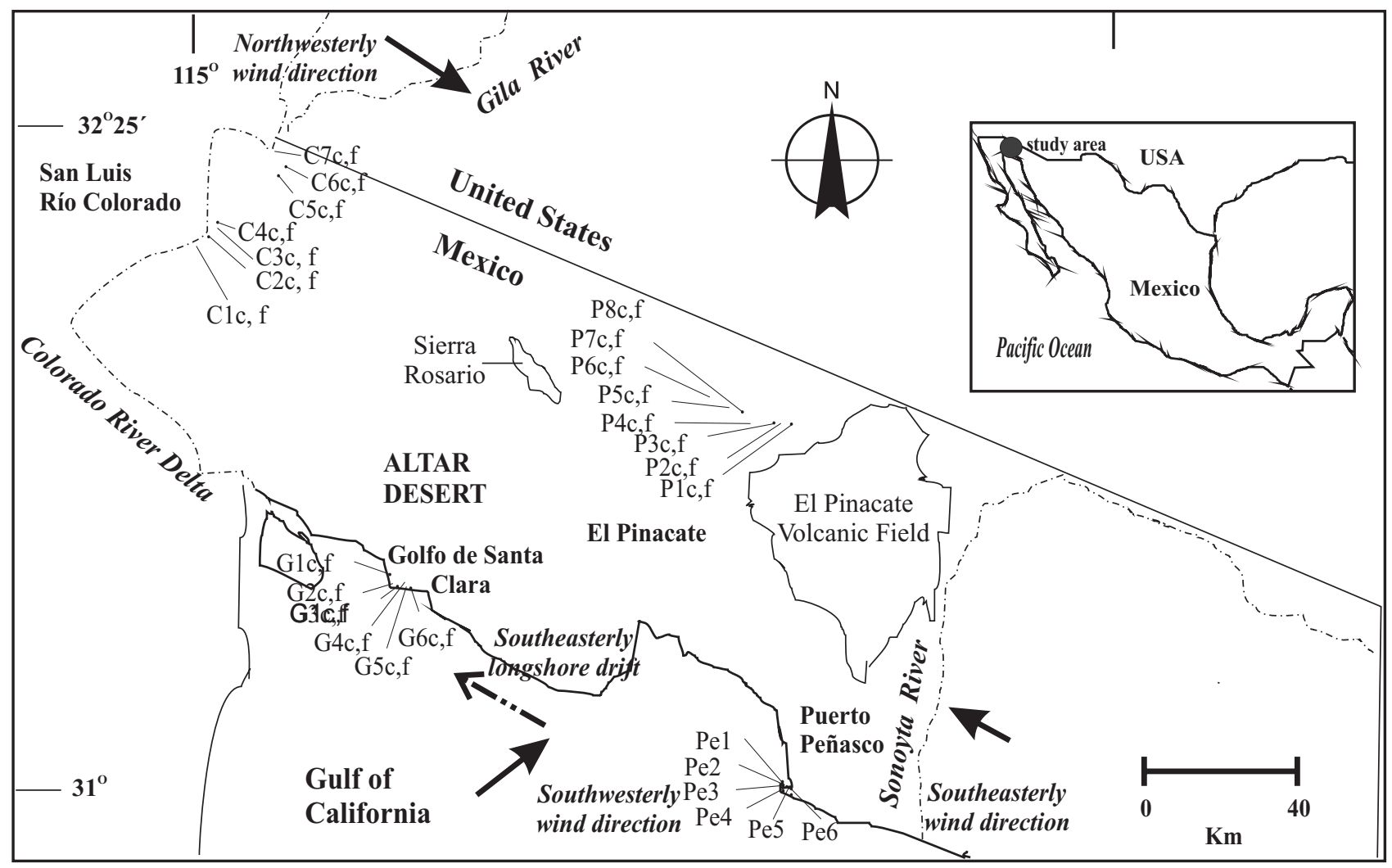

Figure 1. Sampling sites and physiography of the Altar Desert, Sonora, Mexico.

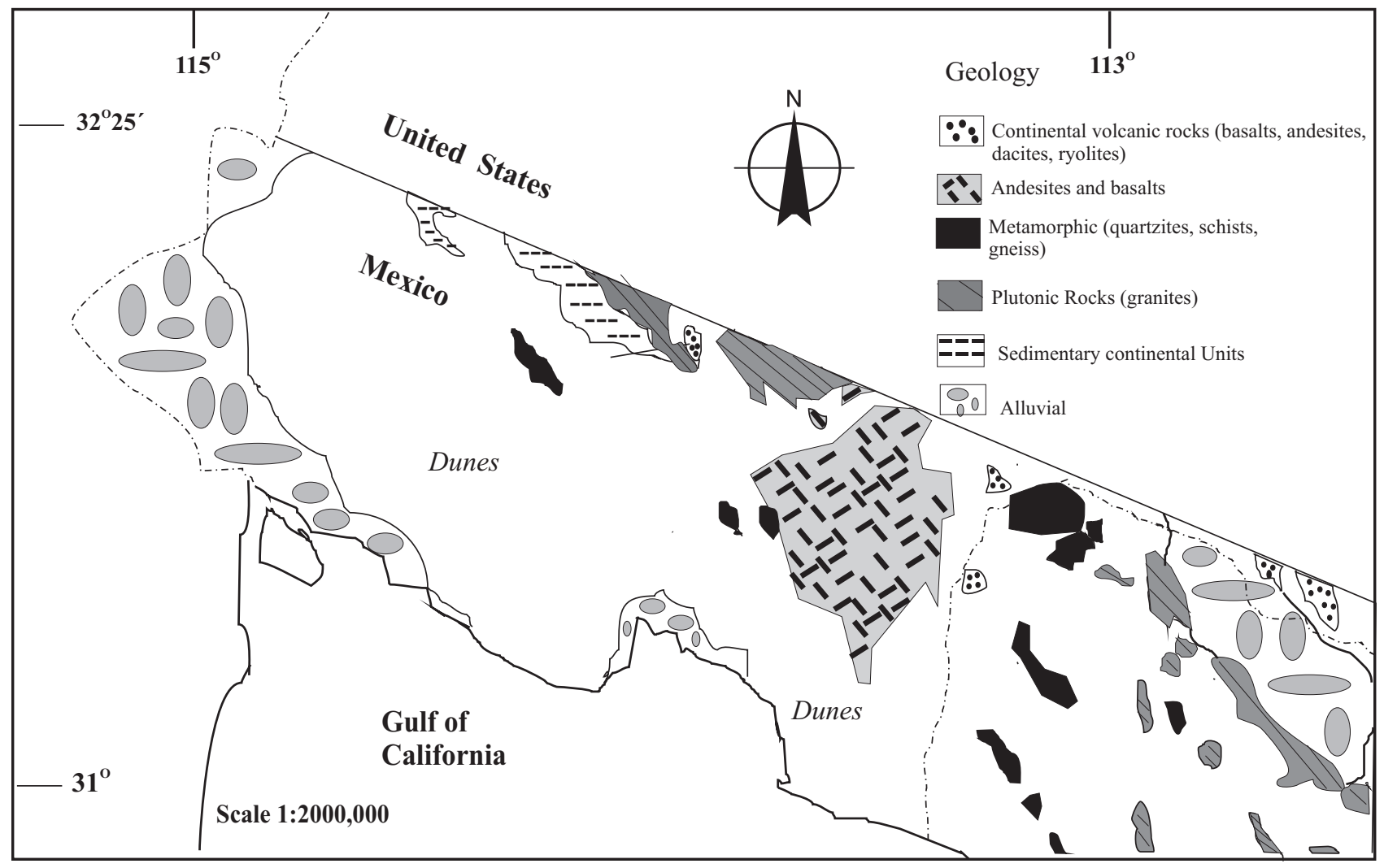

Figure 2. Simplified geology of the studied area. 

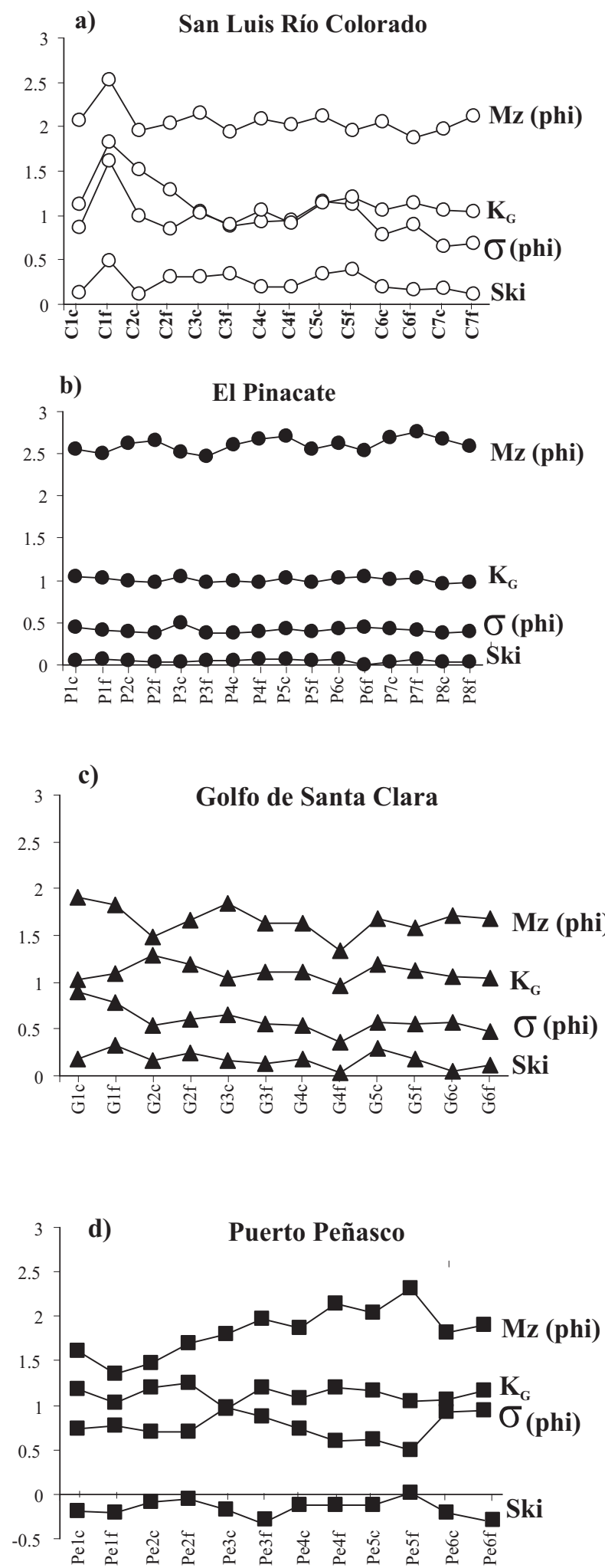

Figure 3. Grain-size trends of four localities studied (a) SLRC, b) EP, c) GSC, d) PP . Mz and $\sigma$ are in phi units. The rest of the grain-size parameters are dimensionless . Locations on axe $\mathrm{x}$ are not at scale. See Table 1 for symbols.
Table 1. Grain size parameters and roundness of quartz grains

\begin{tabular}{|c|c|c|c|c|c|c|c|c|c|c|c|}
\hline $\begin{array}{c}\text { Site } \\
\text { and } \\
\text { Sample }\end{array}$ & $\mathbf{M z}$ & $\sigma$ & Ski & $\mathbf{K}_{\mathrm{G}}$ & MA & $\mathbf{A}$ & SA & SR & $\mathbf{R}$ & MR & tota \\
\hline \multicolumn{12}{|l|}{ SLRC } \\
\hline $\mathrm{Clc}$ & 2.064 & 0.856 & 0.125 & 1.121 & 9 & 14 & 17 & 27 & 23 & 10 & 100 \\
\hline $\mathrm{C} 1 \mathrm{f}$ & 2.528 & 1.609 & 0.491 & 1.828 & 12 & 14 & 16 & 25 & 24 & 9 & 100 \\
\hline $\mathrm{C} 2 \mathrm{c}$ & 1.960 & 1.002 & 0.117 & 1.515 & 6 & 14 & 22 & 26 & 17 & 15 & 100 \\
\hline $\mathrm{C} 2 \mathrm{f}$ & 2.046 & 0.845 & 0.307 & 1.28 & 4 & 15 & 21 & 27 & 21 & 12 & 100 \\
\hline $\mathrm{C} 3 \mathrm{c}$ & 2.147 & 1.046 & 0.314 & 1.026 & 6 & 13 & 25 & 26 & 20 & 10 & 100 \\
\hline $\mathrm{C} 3 \mathrm{f}$ & 1.947 & 0.881 & 0.335 & 0.892 & 2 & 10 & 28 & 26 & 22 & 12 & 100 \\
\hline $\mathrm{C} 4 \mathrm{c}$ & 2.090 & 0.934 & 0.191 & 1.060 & 4 & 14 & 26 & 27 & 17 & 12 & 100 \\
\hline $\mathrm{C} 4 \mathrm{f}$ & 2.024 & 0.951 & 0.191 & 0.920 & 4 & 12 & 25 & 28 & 18 & 13 & 100 \\
\hline $\mathrm{C} 5 \mathrm{c}$ & 2.114 & 1.152 & 0.335 & 1.136 & 11 & 15 & 18 & 25 & 18 & 13 & 100 \\
\hline C5f & 1.963 & 1.133 & 0.391 & 1.202 & 5 & 12 & 17 & 28 & 25 & 13 & 100 \\
\hline C6c & 2.061 & 0.777 & 0.196 & 1.057 & 12 & 16 & 23 & 22 & 19 & 8 & 100 \\
\hline C6f & 1.880 & 0.895 & 0.155 & 1.140 & 9 & 12 & 20 & 27 & 21 & 11 & 100 \\
\hline $\mathrm{C} 7 \mathrm{c}$ & 1.972 & 0.655 & 0.178 & 1.059 & 7 & 9 & 23 & 30 & 20 & 11 & 100 \\
\hline C7f & 2.125 & 0.689 & 0.122 & 1.051 & 6 & 11 & 24 & 28 & 20 & 11 & 100 \\
\hline \multicolumn{12}{|c|}{ 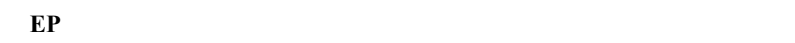 } \\
\hline P1c & 2.562 & 0.449 & 0.057 & 1.046 & 2 & 15 & 37 & 37 & 8 & 1 & 100 \\
\hline P1f & 2.498 & 0.403 & 0.074 & 1.026 & 8 & 20 & 30 & 30 & 11 & 1 & 100 \\
\hline $\mathrm{P} 2 \mathrm{c}$ & 2.617 & 0.393 & 0.052 & 0.995 & 12 & 19 & 19 & 29 & 12 & 9 & 100 \\
\hline $\mathrm{P} 2 \mathrm{f}$ & 2.651 & 0.368 & 0.040 & 0.967 & 9 & 14 & 23 & 30 & 17 & 7 & 100 \\
\hline $\mathrm{P} 3 \mathrm{c}$ & 2.517 & 0.490 & 0.040 & 1.040 & 11 & 15 & 24 & 29 & 17 & 4 & 100 \\
\hline P3f & 2.464 & 0.382 & 0.054 & 0.981 & 14 & 18 & 25 & 28 & 11 & 4 & 100 \\
\hline $\mathrm{P} 4 \mathrm{c}$ & 2.602 & 0.380 & 0.054 & 0.986 & 9 & 17 & 25 & 25 & 19 & 5 & 100 \\
\hline $\mathrm{P} 4 \mathrm{f}$ & 2.677 & 0.385 & 0.059 & 0.982 & 5 & 11 & 24 & 33 & 22 & 5 & 100 \\
\hline $\mathrm{P} 5 \mathrm{c}$ & 2.712 & 0.423 & 0.074 & 1.022 & 12 & 19 & 20 & 30 & 15 & 4 & 100 \\
\hline P5f & 2.547 & 0.386 & 0.043 & 0.977 & 9 & 15 & 23 & 27 & 22 & 4 & 100 \\
\hline P6c & 2.630 & 0.429 & 0.058 & 1.028 & 8 & 16 & 22 & 30 & 19 & 5 & 100 \\
\hline P6f & 2.543 & 0.436 & -0.004 & 1.040 & 9 & 14 & 21 & 30 & 19 & 7 & 100 \\
\hline $\mathrm{P} 7 \mathrm{c}$ & 2.697 & 0.421 & 0.026 & 1.004 & 9 & 17 & 24 & 28 & 16 & 6 & 100 \\
\hline P7f & 2.759 & 0.409 & 0.065 & 1.025 & 7 & 19 & 21 & 27 & 18 & 8 & 100 \\
\hline P8c & 2.680 & 0.371 & 0.035 & 0.951 & 5 & 12 & 25 & 42 & 11 & 5 & 100 \\
\hline P8f & 2.590 & 0.384 & 0.033 & 0.968 & 6 & 13 & 33 & 36 & 11 & 1 & 100 \\
\hline \multicolumn{12}{|l|}{ GSC } \\
\hline G1c & 1.905 & 0.895 & 0.172 & 1.021 & 5 & 6 & 20 & 35 & 28 & 6 & 100 \\
\hline G1f & 1.823 & 0.787 & 0.329 & 1.091 & 7 & 6 & 18 & 29 & 23 & 17 & 100 \\
\hline $\mathrm{G} 2 \mathrm{c}$ & 1.476 & 0.534 & 0.164 & 1.292 & 9 & 16 & 17 & 20 & 22 & 16 & 100 \\
\hline G2f & 1.671 & 0.607 & 0.237 & 1.194 & 9 & 14 & 22 & 25 & 19 & 11 & 100 \\
\hline G3c & 1.850 & 0.653 & 0.159 & 1.050 & 5 & 15 & 21 & 30 & 19 & 10 & 100 \\
\hline G3f & 1.637 & 0.547 & 0.128 & 1.101 & 11 & 14 & 29 & 28 & 15 & 3 & 100 \\
\hline $\mathrm{G} 4 \mathrm{c}$ & 1.629 & 0.534 & 0.178 & 1.108 & 7 & 14 & 19 & 29 & 17 & 14 & 100 \\
\hline $\mathrm{G} 4 \mathrm{f}$ & 1.340 & 0.356 & 0.030 & 0.958 & 7 & 7 & 27 & 30 & 19 & 10 & 100 \\
\hline G5c & 1.679 & 0.576 & 0.286 & 1.190 & 9 & 14 & 25 & 30 & 12 & 10 & 100 \\
\hline G5f & 1.582 & 0.554 & 0.179 & 1.132 & 9 & 16 & 20 & 31 & 18 & 6 & 100 \\
\hline G6c & 1.720 & 0.571 & 0.042 & 1.061 & 2 & 3 & 18 & 45 & 26 & 6 & 100 \\
\hline G6f & 1.677 & 0.479 & 0.115 & 1.044 & 4 & 9 & 25 & 38 & 19 & 5 & 100 \\
\hline \multicolumn{12}{|c|}{ 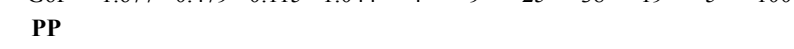 } \\
\hline Pe1c & 1.602 & 0.732 & -0.184 & 1.187 & 5 & 9 & 26 & 40 & 16 & 4 & 100 \\
\hline Pelf & 1.346 & 0.772 & -0.206 & 1.035 & 8 & 7 & 30 & 41 & 11 & 3 & 100 \\
\hline $\mathrm{Pe} 2 \mathrm{c}$ & 1.477 & 0.702 & -0.090 & 1.196 & 15 & 22 & 30 & 25 & 7 & 1 & 100 \\
\hline $\mathrm{Pe} 2 \mathrm{f}$ & 1.693 & 0.700 & -0.051 & 1.246 & 13 & 19 & 26 & 25 & 12 & 5 & 100 \\
\hline $\mathrm{Pe} 3 \mathrm{c}$ & 1.793 & 0.977 & -0.167 & 0.955 & 18 & 18 & 27 & 28 & 5 & 4 & 100 \\
\hline $\mathrm{Pe} 3 \mathrm{f}$ & 1.967 & 0.871 & -0.320 & 1.194 & 10 & 19 & 26 & 27 & 15 & 3 & 100 \\
\hline $\mathrm{Pe} 4 \mathrm{c}$ & 1.876 & 0.741 & -0.123 & 1.085 & 10 & 25 & 26 & 28 & 8 & 3 & 100 \\
\hline $\mathrm{Pe} 4 \mathrm{f}$ & 2.137 & 0.603 & -0.121 & 1.190 & 15 & 23 & 27 & 25 & 6 & 4 & 100 \\
\hline $\mathrm{Pe} 5 \mathrm{c}$ & 2.031 & 0.616 & -0.131 & 1.160 & 15 & 13 & 29 & 25 & 10 & 8 & 100 \\
\hline Pe $5 f$ & 2.308 & 0.498 & 0.022 & 1.039 & 6 & 15 & 26 & 32 & 13 & 8 & 100 \\
\hline Pe6c & 1.808 & 0.931 & -0.208 & 1.060 & 5 & 8 & 24 & 34 & 21 & 8 & 100 \\
\hline Pe6f & 1.900 & 0.946 & -0.301 & 1.167 & 1 & 9 & 30 & 36 & 16 & 8 & 100 \\
\hline
\end{tabular}

$\mathrm{Mz}=$ mean grain size (phi units) $\sigma=$ sorting (phi units); Ski = skewness; $\mathrm{K}_{\mathrm{G}}=$ kurtosis; $\mathrm{VA}=$ very angular; $\mathrm{A}=$ angular; $\mathrm{SA}=$ subangular; $\mathrm{SR}=$ subrounded, $\mathrm{R}=$ rounded; $\mathrm{VR}$ = very rounded 
diagram (Figs. 4 and 5).

Additionally twenty four samples were point counted to identify the main quartz-types such as monocrystalline quartz with straight extinction (MS); undulose extinction (MU) and monocrystalline quartz with inclusions (MI); polycrystalline quartz with macrocrystals $(\sim 30-40 \mu)$ and inclusions (plutonic-type fragments)(PI) and polycrystalline quartz with straight and crenulated boundaries ( $>2$ crystals) (PS) (Blatt and Christie, 1963; Basu, et al., 1975; Harrell and Blatt, 1978; Pye and Mazzullo, 1994) (Tables 2 and 3; Figs. 6 and 7). It should be clarified that the monocrystalline quartz was the only quartz type used for roundness analysis purposes but polycrystalline quartz was observed for additional provenance interpretation.

Data were normalized to $100 \%$ in the same form of modal analysis normalization. Data were plotted in ternary diagrams with the poles VA/A, SA/SR, R/VR and MS, MU and MI. For PI and PS only bivariate diagrams were drawn (Fig.6). In addition, confidence regions (CR) of the whole population at $95 \%$ of confidence level were constructed using the algorithm developed by Weltje (2002) and converted into ellipses using the Sigma Plot software. The ellipses represent the area in which samples might have variations in relation to the whole data limited to three poles of the ternary diagram. Therefore, the CR define rigorously if two data sets are significantly different in the triangle (Weltje, 2002)(Figs. 5 and 7).

A Pearson correlation was carried out for textural $(\mathrm{Mz}$, $\sigma$, Ski, $\mathrm{K}_{\mathrm{G}}$ ), roundness ratios (VA/A, SA/SR and R/VR) and quartz-types (MS, MU, MI, PI and PS) combining the sites SLRC and EP in one correlation and GSC and PP in other correlation (Tables 4 and 5).
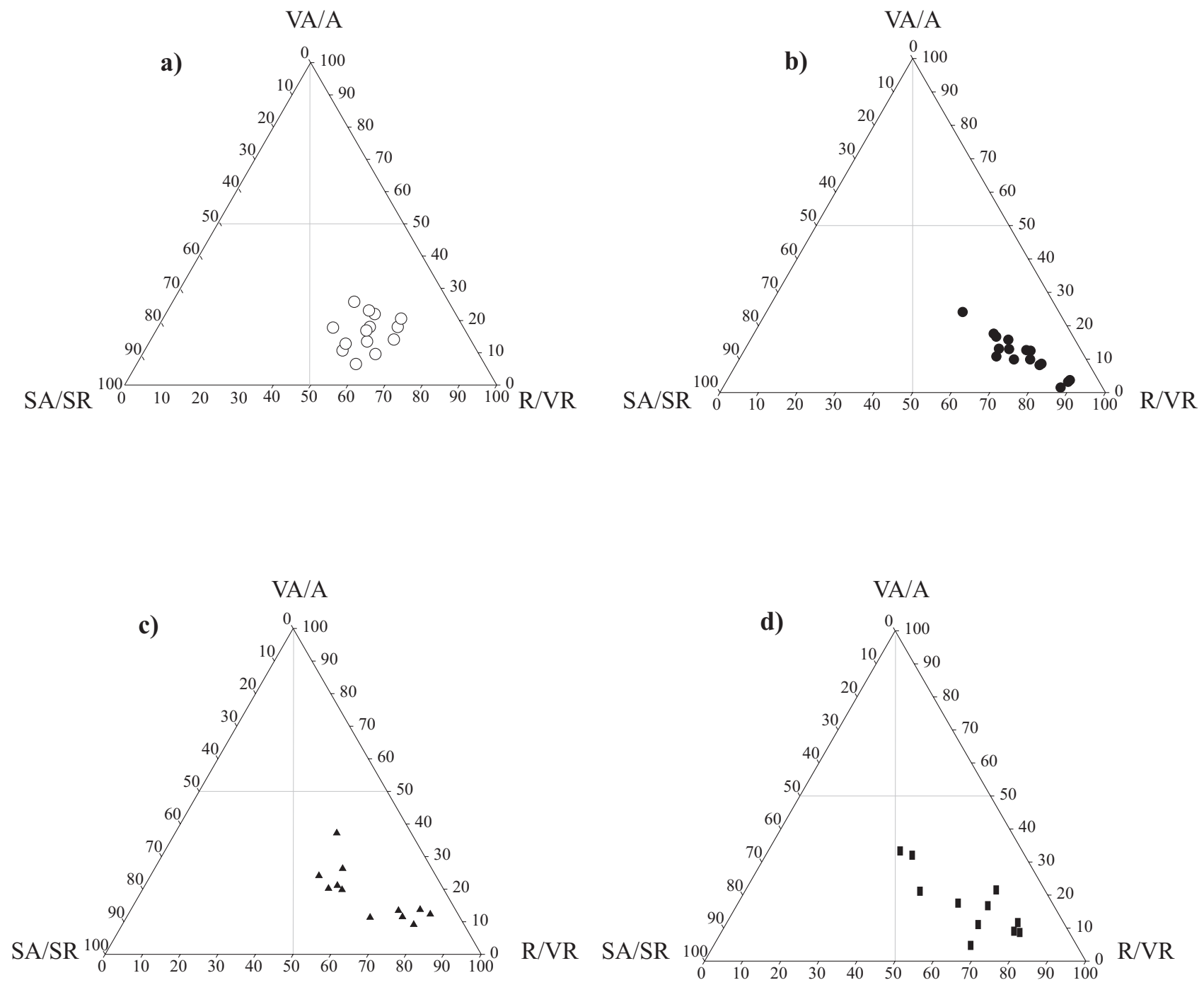

Figure 4. Ternary diagram with samples from sites a) SLRC, b) EP, c) GSC, d) PP. Poles are VA/A, SA/SR, and R/VR. Open circles= San Luis Río Colorado. Filled circles $=$ El Pinacate. Filled triangles $=$ Golfo de Santa Clara. Filled squares $=$ Puerto Peñasco. 


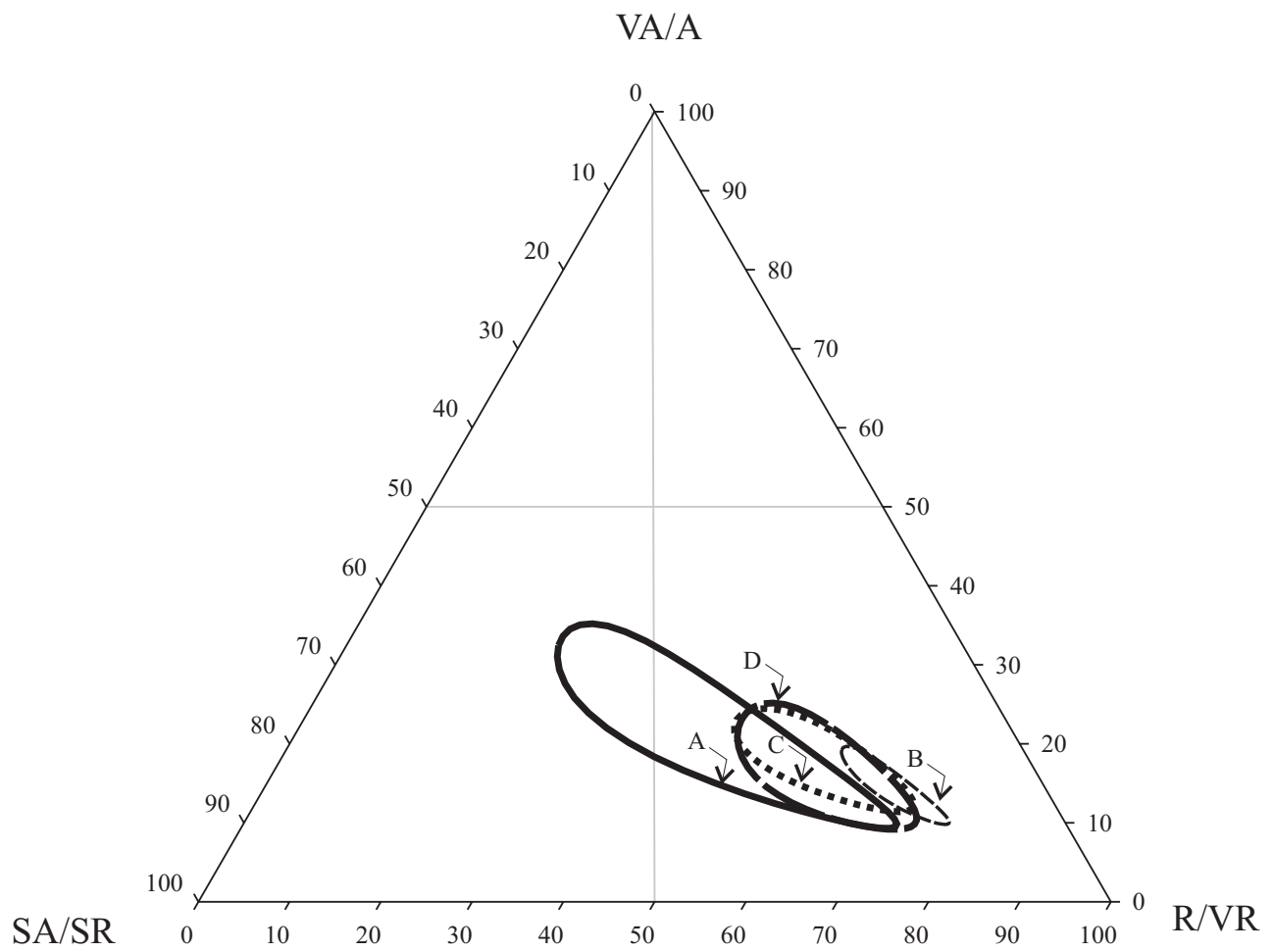

Figure 5. Ternary diagram with $C R$ at $95 \%$ confidence levels. $A=S L R C, B=E P, C=G S C, D=P P$. See text for abreviations.

Table 2. Monocrystalline quartz types percentages

\begin{tabular}{ccccccccc}
\hline Sample & MS & \% MS & MU & \% MU & MI & \% MI & TOTAL & \% TOTAL \\
\hline C1 - c & 48 & 48.5 & 46 & 46.5 & 5 & 5.1 & 99 & 100 \\
C2 - c & 43 & 47.3 & 42 & 46.2 & 6 & 6.6 & 91 & 100 \\
C3 - c & 49 & 52.1 & 43 & 45.7 & 2 & 2.1 & 94 & 100 \\
C1 - f & 42 & 45.2 & 49 & 52.7 & 2 & 2.2 & 93 & 100 \\
C2 - f & 37 & 39.8 & 53 & 57.0 & 3 & 3.2 & 93 & 100 \\
C3 - f & 35 & 40.2 & 51 & 58.6 & 1 & 1.1 & 87 & 100 \\
P1 - c & 45 & 44.6 & 53 & 52.5 & 3 & 3.0 & 101 & 100 \\
P2 - c & 45 & 48.9 & 44 & 47.8 & 3 & 3.3 & 92 & 100 \\
P3 - c & 45 & 50.0 & 43 & 47.8 & 2 & 2.2 & 90 & 100 \\
P1 - f & 28 & 31.1 & 62 & 68.9 & 0 & 0.0 & 90 & 100 \\
P2 - f & 50 & 52.1 & 45 & 46.9 & 1 & 1.0 & 96 & 100 \\
P3 - f & 55 & 57.9 & 40 & 42.1 & 0 & 0.0 & 95 & 100 \\
G1 - c & 50 & 54.3 & 42 & 45.7 & 0 & 0.0 & 92 & 100 \\
G2 - c & 45 & 52.3 & 35 & 40.7 & 6 & 7.0 & 86 & 100 \\
G3 - c & 40 & 42.6 & 50 & 53.2 & 4 & 4.3 & 94 & 100 \\
G1 - f & 48 & 48.5 & 49 & 49.5 & 2 & 2.0 & 99 & 100 \\
G2 - f & 45 & 44.6 & 54 & 53.5 & 2 & 2.0 & 101 & 100 \\
G3 - f & 58 & 47.9 & 57 & 47.1 & 6 & 5.0 & 121 & 100 \\
Pe1 - c & 45 & 52.3 & 35 & 40.7 & 6 & 7.0 & 86 & 100 \\
Pe2 - c & 53 & 57.0 & 37 & 39.8 & 3 & 3.2 & 93 & 100 \\
Pe3 - c & 42 & 46.7 & 45 & 50.0 & 3 & 3.3 & 90 & 100 \\
Pe1 - f & 48 & 53.3 & 42 & 46.7 & 0 & 0.0 & 90 & 100 \\
Pe2 - f & 43 & 48.3 & 44 & 49.4 & 2 & 2.2 & 89 & 100 \\
Pe3 - f & 49 & 46.7 & 54 & 51.4 & 2 & 1.9 & 105 & 100 \\
\hline & & & & & & & &
\end{tabular}

Monocrystalline quartz with straight extiction (MS); undulose extiction (MU) and monocrystalline quartz with inclusions (MI).
Table 3. Polycrystalline quartz types percentages

\begin{tabular}{ccccccc}
\hline Sample & PI & $\%$ PI & PR & $\%$ PR & TOTAL & $\%$ TOTAL \\
\hline C1 - c & 2 & 16.7 & 10.0 & 83.3 & 12.0 & 100 \\
C2 - c & 3 & 15.0 & 17.0 & 85.0 & 20.0 & 100 \\
C3 - c & 0 & 0.0 & 14.0 & 100.0 & 14.0 & 100 \\
C1 - f & 2 & 13.3 & 13.0 & 86.7 & 15.0 & 100 \\
C2 - f & 1 & 11.1 & 8.0 & 88.9 & 9.0 & 100 \\
C3 - f & 1 & 6.3 & 15.0 & 93.8 & 16.0 & 100 \\
P1 - c & 0 & 0.0 & 8.0 & 100.0 & 8.0 & 100 \\
P2 - c & 0 & 0.0 & 11.0 & 100.0 & 11.0 & 100 \\
P3 - c & 0 & 0.0 & 5.0 & 100.0 & 5.0 & 100 \\
P1 - f & 1 & 9.1 & 10.0 & 90.9 & 11.0 & 100 \\
P2 - f & 0 & 0.0 & 9.0 & 100.0 & 9.0 & 100 \\
P3 - f & 0 & 0.0 & 10.0 & 100.0 & 10.0 & 100 \\
G1 - c & 0 & 0.0 & 12.0 & 100.0 & 12.0 & 100 \\
G2 - c & 2 & 13.3 & 13.0 & 86.7 & 15.0 & 100 \\
G3 - c & 2 & 18.2 & 9.0 & 81.8 & 11.0 & 100 \\
G1 - f & 1 & 5.3 & 18.0 & 94.7 & 19.0 & 100 \\
G2 - f & 3 & 25.0 & 9.0 & 75.0 & 12.0 & 100 \\
G3 - f & 5 & 33.3 & 10.0 & 66.7 & 15.0 & 100 \\
Pe1 - c & 4 & 26.7 & 11.0 & 73.3 & 15.0 & 100 \\
Pe2 - c & 2 & 9.5 & 19.0 & 90.5 & 21.0 & 100 \\
Pe3 - c & 4 & 21.1 & 15.0 & 78.9 & 19.0 & 100 \\
Pe1 - f & 0 & 0.0 & 10.0 & 100.0 & 10.0 & 100 \\
Pe2 - f & 0 & 0.0 & 13.0 & 100.0 & 13.0 & 100 \\
Pe3 - f & 0 & 0.0 & 12.0 & 100.0 & 12.0 & 100 \\
\hline
\end{tabular}

Polycrystalline quartz with macrocrystals $(\sim 30-40 \mu)$ and inclusions (plutonic-type fragments)(PI) and polycrystalline quartz with straight and crenulated boundaries ( $>2$ crystals)(PS). 

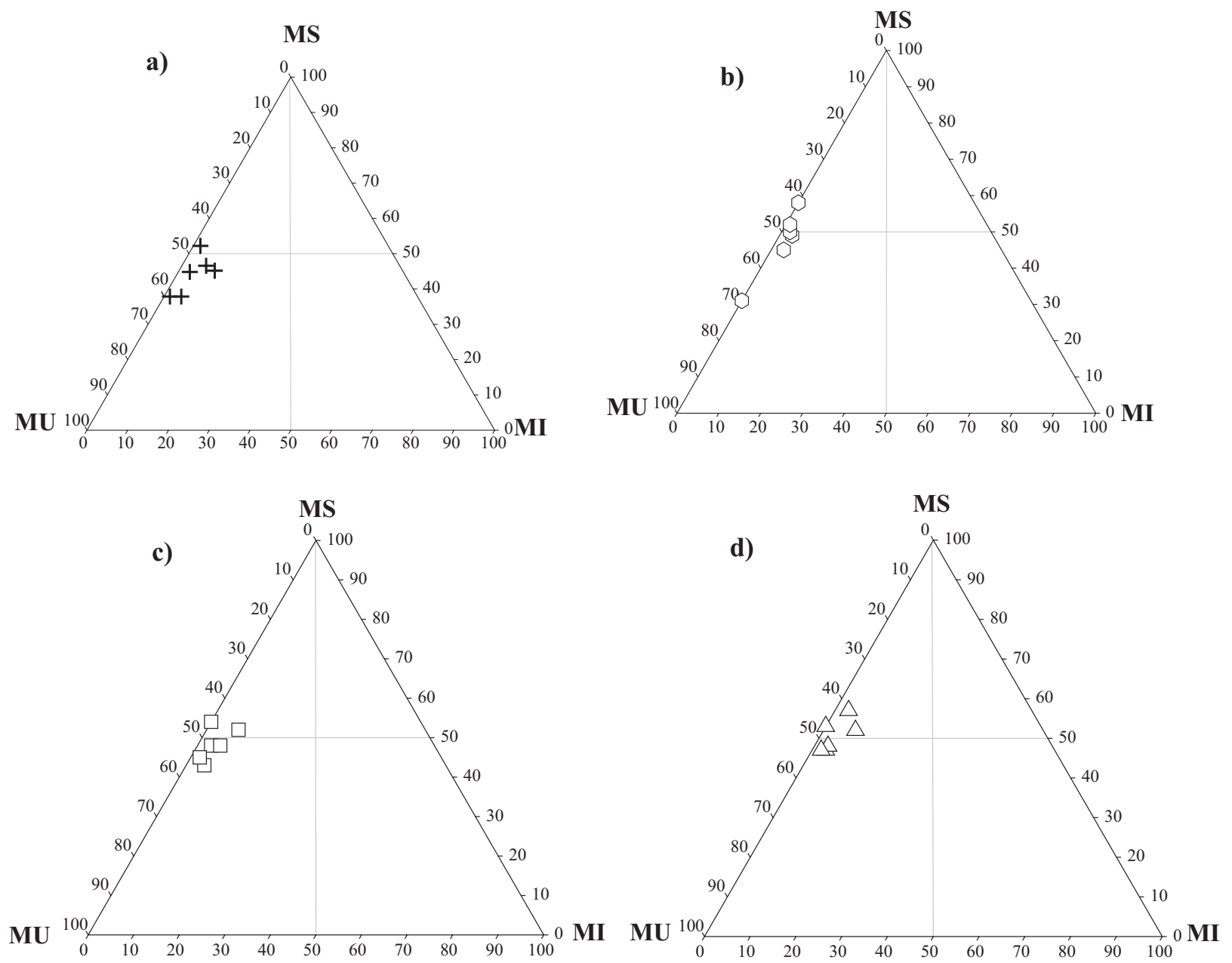

Figure 6. Ternary diagram with samples from sites a) SLRC, b) EP, c) GSC, d) PP. Poles are MS, MU and MI. Crosses = San Luis Río Colorado. Open hexagons $=$ El Pinacate. Open squares $=$ Golfo de Santa Clara. Open triangles $=$ Puerto Peñasco.

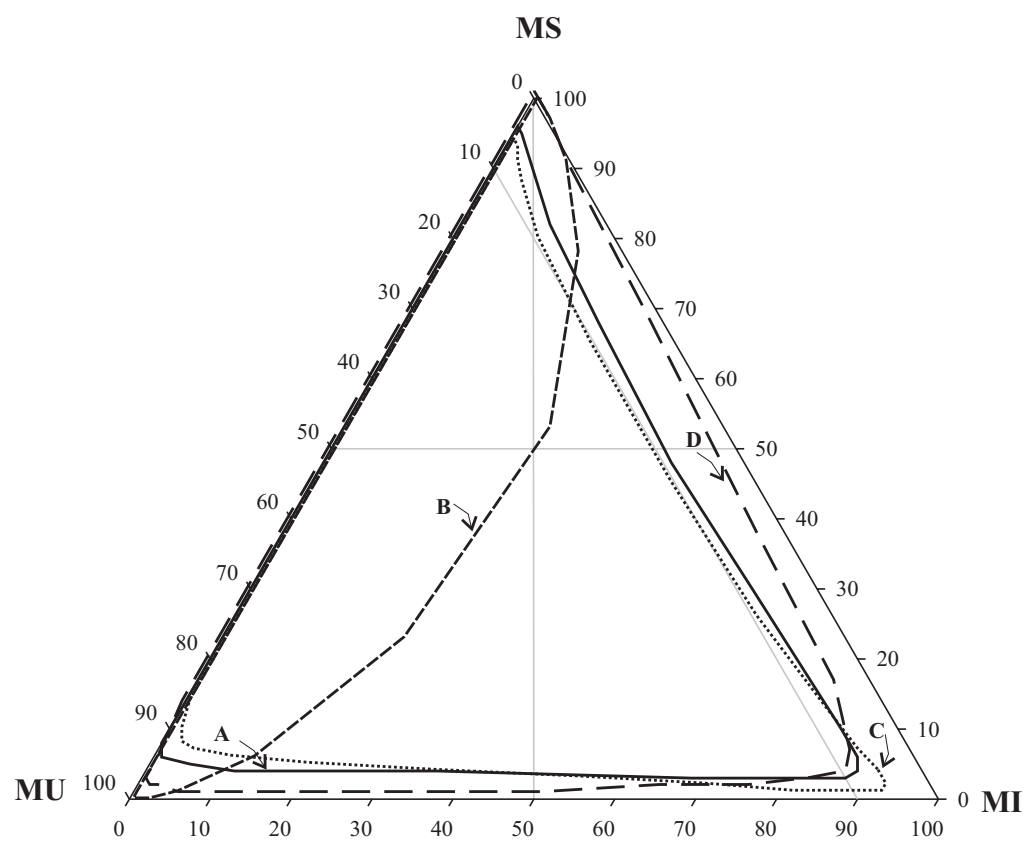

Figure 7. Ternary diagram with $\mathrm{CR}$ at $95 \%$ confidence levels. $\mathrm{A}=\mathrm{SLRC}, \mathrm{B}=\mathrm{EP}, \mathrm{C}=\mathrm{GSC}, \mathrm{D}=\mathrm{PP}$. See text for abreviations. 


\section{Results}

\subsection{Grain size parameters}

Grain size parameters show that dune sands from San Luis Río Colorado (SLRC) and El Pinacate (EP) are finegrained moderately to well sorted sands. Skewness indicates that the sands are fine-skewed and symmetrical respectively. Kurtosis shows that the sands are leptokurtic with the central part of the distribution better sorted than the tails. Coastal dune sands from Golfo de Santa Clara (GSC) and Puerto Peñasco (PP) are medium moderately well sorted sands (Table 1). Skewness indicates that the sands are fine and coarse-skewed respectively. Kurtosis values also reflect the leptokurtic character of the distributions (Fig. 3). It can be observed that the El Pinacate dune sands are the finest of all four sites (Fig. 3b).

\subsection{Roundness of quartz grains}

It can be observed that samples from SLRC and EP are slightly better grouped (Figs. $4 \mathrm{a}, \mathrm{b}$ ) than samples from the sites GSC and PP (Figs.4 c, d) which are slightly more scattered with trends towards the R/VR pole. The CR for the roundness ratios plotted in the ternary diagram shows that there is a significative difference between roundness of quartz coming from SLRC and roundness from quartz coming from EP (Fig. 5). The rest of the sites overlap.

\subsection{Quartz types}

Dispersal towards the MS-MU poles of quartz coming from EP is observed in the MS-MU-MI ternary plot (Fig. $6 \mathrm{~b}$ ). The rest of the samples are slightly grouped in the middle of the triangle towards the MS-MU poles (Fig. 6 a, c, d). The CR for the four sites overlap and large dispersal in the ternary diagram is due to: a) low number of samples that enhance the CR area; b) dispersal of the whole data set plotted in the triangle (Weltje, 2002) (Fig. 7). The bivariate digrams shows that sites EP and PP have polycrystalline quartz with straight and undulose extinction that dominates almost in $100 \%$ the sands (Fig. 8 a, d). The rest of the sites are composed of mixed policrystalline quartz types such as plutonic and straight-undulose extinction types (Fig. 8 b, c).

4.4. Pearson correlations among grain-size parameters, roundness and quartz types

The most significant and meaningful Pearson correlations of samples from sites SLRC and EP are between Mz vs. SA/ SR and VA/A vs. MU and between R/VR vs. PI and R/VR vs. PS for GSC and PP sites (Tables 4 and 5).
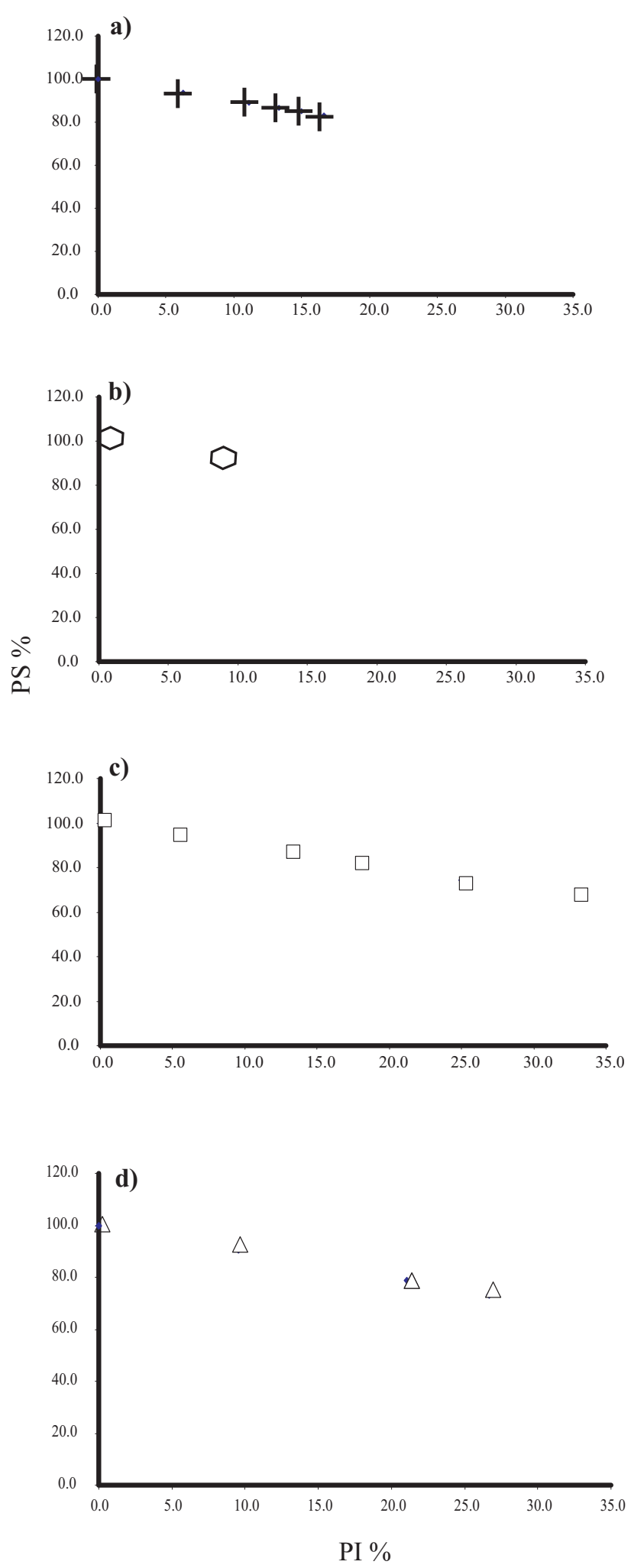

Figure 8. Binary plots of PI \%vs. PS \%, A= SLRC, B=EP; $=\mathrm{GSC}, \mathrm{D}=$ PP. See text for abreviations. 


\section{Discussion}

\subsection{Grain size parameters}

Fine-grained sizes in SLRC and EP dune sands may be the result of aeolian transport that carries fine particles onto the dune. Also, wind transport gives selectiveness in the form of moderately to well sorted sands (KasperZubillaga and Carranza-Edwards, 2005). Fine-skewed and symmetrical distributions in SLRC and EP sites respectively indicate the aeolian influence and probably short transport from the source into the SLRC dune fields and long transport from the source into the EP dune fields. This interpretation is supported by the sorting character of the dune sands from each of these two sites (i.e. moderately to well sorted sands respectively) (Khalaf, 1989; Wang et al., 2003; Blount and Lancaster, 1990). Sources are in the proximity of alluvial deposits of the Colorado River Delta and plutonic rocks exposed near the US-Mexican Border (Lancaster, 1992; Muhs, et al., 2003; Kasper-Zubillaga et al, 2007).

The GSC and PP medium moderately well sorted coastal dune sands suggest mixing of aeolian/marine processes that generate different grain sizes of different composition (i.e.terrigenous / biogenic sands). High tidal regimes in the coastal area along the beaches also affect the transport of shell debris and sand landwards during long periods of beach exposure to the southwesterly onshore winds (Kasper-Zubillaga and Carranza-Edwards, 2005). Skewness indicates the coastal processes influence in the characteristics of the coastal dune sands and tke kurtosis still enforces the aeolian mechanisms that prevail in the coastal area. This symmetrical distributions represented by leptokurtic curves have been also observed in dune sands from Kuwait (Khalaf, 1989).

\subsection{Roundness of quartz grains.}

\subsubsection{Inland dune sands}

The SLRC and EP are slightly grouped towards the R/ VR pole indicating that quartz grains have been subjected to a) a fluvial transport that has deposited sediments in the Colorado River Delta which may be still inheriting the roundness features from the past b) quartz grains coming from the Colorado River Delta that retain their roundness characteristics until they are deposited by aeolian action in the SLRC site, c) long-lasting transport from the Colorado River Delta to the EP site in which roundness is attributed to inheritance from the source sediments but also to the long aeolian transport. These interpretations are also supported by the findings in scanning electron microscopy analysis (SEM) carried out in quartz grains form SLRC and EP which they evidenced the presence of mechanical surface features in the form of conchoidal fractures and smooth surfaces distinctive of fluvial environments and aeolian transport respectively (Krinsley and Margolis 1969; Margolis and Kennet, 1971; Higgs, 1979; Kasper-Zubillaga and Faustinos
Morales, 2007) (Fig. 9).

Furthermore, it seems that when the CR is plotted in the ternary diagram a clearer interpretation can be made in terms of roundness ratios. The CR indicate that SLRC and EP are significant different in terms of roundness values being the SLRC site more influenced by angular and subrounded quartz grains (SA/SR ratio) due to the larger dispersal of the CR ellipse compared to the EP site (Fig. 5). This suggests

a)

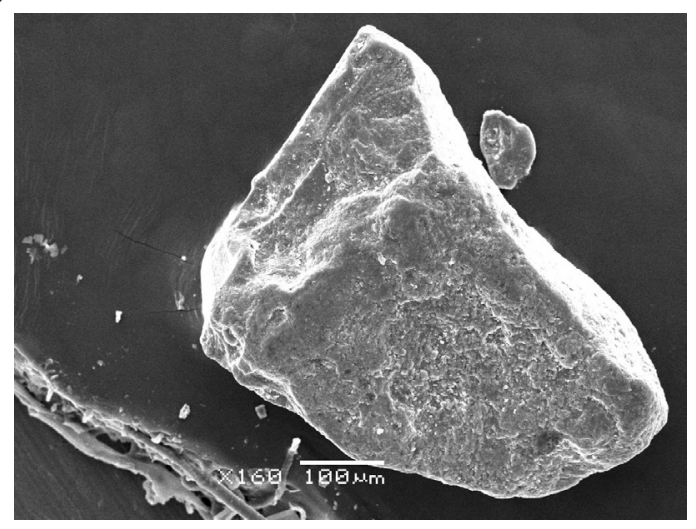

b)

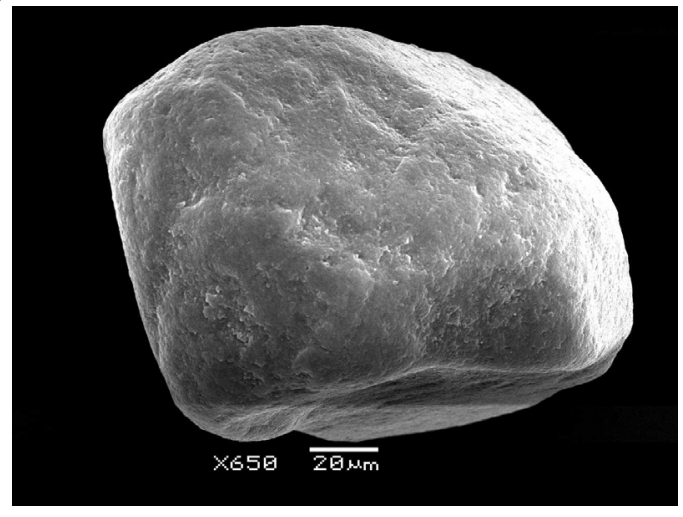

c)

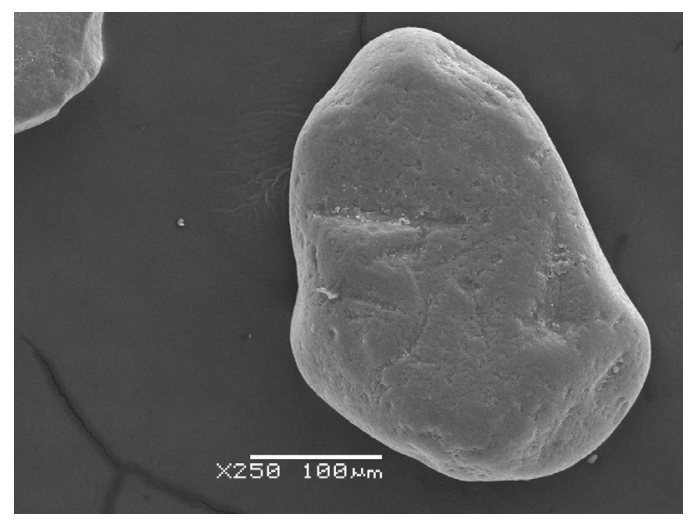

Figure 9. Scanning electron microscopy photomicrographs of quartz grains with a) conchoidal fractures (sample C5f-SLRC) b) and c) smooth surfaces (samples PC6c and Pc7f- EP). 
that the SLRC indeed concentrates more quartz grains with less aeolian transport compared to the EP which has more rounded and abraded quartz grains. In both sites, quartz may be dominantly sourced from alluvial deposits from the Colorado River Delta by northwesterly and northerly winds as it was evidenced by previous SEM, petrographic and geochemical studies (Kasper-Zubillaga et al., 2007; Kasper-Zubillaga and Faustinos Morales, 2007) (Fig. 9).

\subsubsection{Coastal dune sands}

The GSC and PP slight dispersal towards the VA/A and $\mathrm{R} / \mathrm{VR}$ poles indicates that quartz grains have suffered marine/aeolian transport that may caused some samples to retain angulosity due to high energy derived from longshore transport and collision fron one grain to another in a subacqueous and even in aerial environments This interpretation is supported by the fact that some quartz grains experience collisions that leads to angulosity and even conchoidal fractures in the grains in both water and land (Krinsley and Donahue, 1968). Roundness may be produced mainly by aeolian transport in some quartz grains.

The CR from the ternary diagram for sites GSC and PP shows a slight dispersal towards the VA/A poles being the R/VR pole the most significant. Both sites overlap which represents that they are not significantly different. The preceding results suggests that the GSC and PP are influenced by a mix of marine/aeolian processes that gives quartz grains with angularity and roundness attributed to high energy coastal process like longshore currents and wind tranport respectively.

\subsection{Quartz types}

\subsubsection{Inland dune sands}

Samples from sites SLRC and EP plot in the middle of the ternary diagram with slight dispersal towards the MS and MU poles (Fig. 6 a, b). This represents high content of monocrystalline quartz with straight and undulose extinction. Undulatory quartz is less stable than straight extinction quartz (Blatt and Christie, 1963) but its preservation in the dunes may be due to less transport and closeness to the source sediments in the Colorado River Delta. It is likely that both quartz types are derived from some plutonic and low-rank metamorphic rocks exposed north of the Altar Desert and deposited in the continental sedimentary units (Fig. 2). Also, durability of less stable quartz types like undulatory quartz has been reported in dune sands from New Zealand due to little abrasion exerted by the wind (Kasper-Zubillaga et al., 2005).

The CR for samples coming from EP site shows a narrower area compared to the SLRC site. This can be attributed to the dispersal of the EP site samples towards the poles MS and MU. The CR area of SLRC reflect only the amount of samples analyzed. (Fig. 7).

From the binary diagrams it is observed that polycrystalline quartz with straight and crenulated boundaries dominate the samples from the EP site. This quartz type is probably derived from plutonic rocks (Fig. $8)$. The SLRC site shows a relatively mixed percentages of polycrystalline quartz of plutonic origin and low-rank metamorphic sources (Fig. 8).

\subsubsection{Coastal dune sands}

Samples from sites GSC and PP are grouped in the middle of the ternary diagram by the side of the MS and MU poles (Fig. 6 c, d). Dune sands from these two coastal sites are dominated, like inland dune sands, by monocrystalline quartz with straight and undulose extinction derived from plutonic and low-rank metamorphic rocks.

The CR for samples coming from GSC and PP extend their areas towards the MI pole. However, this pattern only reflects the prediction regions in which the population extends with the little number of samples used for the analysis (Weltje, 2002).

From the binary diagrams it is observed that polycrystalline quartz with straight and crenulated boundaries and plutonic-type fragments are mixed in relatively constant percentages at sites GSC and P.

\subsection{Pearson correlations among grain-size parameters,} roundness and quartz types.

The SLRC and EP sites showed Mz vs. SA/SR and VA/A vs. MU as significant correlations. The Mz vs. SA/ SR negative correlation (-0.70) suggests that coarse-sized grains are subangular probably due to little abrasion and rounding of grain edges trough transport. This interpretation can be supported by the test-tube experiment by Whalley et al., (1987) in which after 48 hours of mechanical attrition quartz grains become more rounded and finer compared to the initial stages of the test-tube experiment (Tables 4 and 5). The VA/A vs. MU negative correlation (-0.68) suggests that angular grains are mainly monocrystalline quartz with undulose extinction probably derived from low-rank metamorphic sources. Preservation of undulose quartz, which is less stable that non-undulatory quartz, may be due to little transport from the source to the dune fields reflected by the angulosity of the quartz.

The GSC and PP sites show that a meaningful correlation is between Mz vs. SA/SR (0.60) suggesting that increasing of grain size increases angularity of the grains. This may be in opposition to the negative correlation found for the sands coming from SLRC and EP. However, in the case of GSC and PP sites, grain size is coarser than sands from SLRC and EP. Therefore this may have implications in the positive correlation between $\mathrm{Mz}$ vs. SA/SR.

\section{Conclusions}

Fine-grained and moderately to well sorted sands in SLRC and EP dune sands are generated by aeolian transport 
and wind selectiveness. In contrast, medium sand sizes and moderately well sorted coastal dune sands at sites GSC and PP indicate a mix of aeolian/marine processes that also generate different grain sizes of different composition (i.e.terrigenous/ biogenic detritus).

Roundness of quartz grains at sites SLRC and EP suggests fluvial transport that might inherit their roundness from the Colorado River Delta. However, roundness may be also generated by long wind transport from the Colorado River Delta towards the EP site.

The presence of angular and rounded quartz grains at the GSC and PP may be due to the mixing of aeolian/ marine processes. This is because grain to grain collisions may generate angular quartz grains. In contrast, rounded quartz grains are probably produced by aeolian transport

Samples from sites SLRC and EP concentrate monocrystalline quartz with straight and undulose extinction probably derived from a near source sediment (i.e. Colorado River Delta) since undulatory quartz is more likely to be weathered compared to other quartz types after long transport. Samples from sites GSC and PP are dominated by monocrystalline quartz with straight and undulose extinction derived from plutonic and low-rank metamorphic rocks.

Polycrystalline quartz with straight and crenulated boundaries dominates the samples from the EP site. This quartz type is probably derived from plutonic rocks. The SLRC site shows a relatively mixed percentages of polycrystalline quartz of plutonic origin and low-rank metamorphic sources. Polycrystalline quartz with straight and crenulated boundaries and plutonic-type fragments are mixed in relatively constant percentages at sites GSC and PP.

A negative correlation between Mz vs. SA/SR indicates that coarse-sized grains are subangular probably due to little abrasion and rounding of grain edges trough transport at SLRC and EP sites. The VA/A vs. MU negative correlation suggests that angular grains are mainly monocrystalline quartz with undulose extiction probably derived from low-rank metamorphic sources. The GSC and PP sites show that a meaningful correlation is between $\mathrm{Mz}$ vs. SA/ SR suggesting an increase of grain size in relation to the angularity of the grains. This may in opposition to the negative correlation found for the sands coming from SLRC and EP due to coarser sizes in sites GPS and PP compared to sites SLRC and EP.

\section{Acknowledgments}

We appreciate to Eduardo Morales de la Garza for his invaluable assistance in the Particle Size Analysis at the Sedimentological Laboratory of the Instituto de Ciencias del Mar y Limnología, Universidad Nacional Autónoma de México.

\section{References}

Andrews, E.D., 1991, Sediment transport in the CR basin Colorado River Ecology and Dam Management, in Proceedings of a Symposium National Academic Press: Washington DC, 54-74.

Basu, A., Young, S.W., Suttner, L.J., James, W.C., Mack, G.H., 1975, Reevaluation of the use of undulatory extinction and polycrystallinity in detrital quartz foe provenance interpretation: Journal of Sedimentary Petrology, 45, 873-882.

Basu, A., 1985, Reading provenance from detrital quartz, in Zuffa G.G.I., Provenance of Arenites: Nato Series C. 148, 231-247.

Beal, M.A., Shepard, F.P., 1956, A use of roundness to determine depositional environments: Journal of Sedimentary Petrology, 26: 49-60.

Blatt, H., Christie, J.M., 1963, Undulatory extinction in quartz of igneous and metamorphic rocks and its significance in provenance studies of sedimentary rocks: Journal of Sedimentary Petrology, 33: 559579 .

Blount, G., Lancaster, N., 1990, Development of the Gran Desierto sand sea: Geology 18: 724-728.

Cupul, M.A.L.,1994, Flujos de sedimentos en suspensión y nutrientes en la cuenca estuarina del Río Colorado Ensenada, B.C., Mexico: Ensenada, Baja Californa, Mexico, Facultad de Ciencias Marinas, Universidad Autónoma de Baja California master in science thesis.

Folk, R.L., 1978, Petrology of Sedimentary Rocks: Austin Texas, Hemphil Public. 182p.

Harrell J., Blatt, H., 1978, Polycrystallinity: effect on the durability of detrital quartz: Journal of Sedimentary Petrology, 48: 25-30.

Higgs, R., 1979, Quartz-grain surface features of Mezosoic-Cenozoic sands from the Labrador and western Greenland continental margins: Journal of Sedimentary Petrology, 49, 599-610.

Kasper-Zubillaga, J.J., Dickinson, W.W., Carranza-Edwards, A., HornelasOrozco, Y., 2005, Petrography of quartz grains in beach and dune sands of Northland, North Island, New Zealand: Journal of Geology and Geophysics, 48, 649-660.

Kasper-Zubillaga, J.J., Carranza-Edwards, A., 2005, Grain size discrimination between sands of desert and coastal dunes from Northwestern Mexico: Revista Mexicana de Ciencias Geológicas ,22, 383-390.

Kasper-Zubillaga, J.J., Zolezzi-Ruíz, H., Carranza-Edwards, A., GirónGarcía, P., Ortiz-Zamora, G., Palma, M., 2007, Sedimentological, modal analysis and geochemical studies of desert and coastal dune sands, Altar Desert, NW Mexico: Earth Surface Processes and Landforms, 32, 489-508.

Kasper-Zubillaga, J.J., Faustinos Morales, R., 2007, Scanning electron microscopy analysis of quartz grains in desert and coastal dune sands (Altar Desert, NW Mexico): Ciencias Marinas, 33, 11-22.

Khalaf, F., 1989, Textural characteristics and genesis of the aeolian sediments in the Kuwaiti desert: Sedimentology, 36, 253-271.

Krinsley, D., Donahue, J., 1968, Environmental interpretation of sand grain surface textures by electron microscopy: Geological Society of America Bulletin, 79, 743-748.

Krinsley, D., Margolis, S., 1969, Scanning electron microscopy: a new method for studying sand grain surface textures: Transactions of New York Academy of Science, 31, 457-477.

Lancaster, N., Greeley, R., Christensen, P.R., 1987, Dines of the Gran Desierto sand Sea, Sonora, Mexico: Earth Surface Processes and Landforms, 12, 277-288.

Lancaster, N., 1992, Relations between dune generations in the Gran Desierto of Mexico: Sedimentology, 39, 631-644.

Lavin, M.F., Badan-Dangon, A, 1997, Estructura hidrográfica y circulación del Golfo de California, in Lavin, M.F., Contribuciones a la Oceanografía Física en México: Monografía 5.

Margolis, S.V., Kennet, J.P., 1971, Cenozoic paleoglacial history of Antarctica recorded in subantarctic deep-sea cores: American Journal of Science, 271, 1-36.

Marinone, S.G., Lavin, M.F., 1997, Mareas y corrientes residuales en el 
Golfo de California, in Lavin M.F., Contribuciones a la Oceanografía Física en México. Unión Geofísica Mexicana, México, 117-143.

Muhs, D.R., Reynolds, R.L., Been, J., Skipp, G., 2003, Eolian sand transport pathways in the southwestern United States: importance of the Colorado River and local sources: Quaternary International, 104, 3-18.

Pettijohn, F.J., Potter, P.E., Siever, R., 1972, Sand and Sandstone: SpringerVerlag, $618 \mathrm{p}$.

Powers, M.C., 1953, A new roundness scale for sedimentary particles, Journal of Sedimentary Petrology, 23, 117-119.

Pye, K., Mazullo, J., 1994, Effects of tropical weathering on quartz shape: an example from northeastern Australia: Journal of Sedimentary Research A, 64, 500-507.

Sagga, A.M.S., 1993, Roundness of sand grains of longitudinal dunes in Saudi Arabia: Sedimentary Geology, 87, 63-68.

Shepard, F.P., Young, R., 1961, Distinguishing between beach and dune sands: Journal of Sedimentary Petrology, 31, 196-214.

Shepard, F.P., 1973, Submarine Geology: Harper and Row, New York, $517 \mathrm{p}$

Thompson, R.W., 1968, Tidal flat sedimentation on the Colorado River Delta, northwestern Gulf of California: Bulletin of the Geological Society of America Memoir, 107.

Vandivere, W.B., Vorster, P., 1984, Hydrology analysis of the CR floods of 1983: Geojournal, 9, 343-350.
Whalley, W.B., Smith, B.J., McAlister, J.J., Edwards, A.J., 1987, Aeolian abrasion of quartz particles and the production of silt-size fragments: preliminary results, in Frostick L., Reis I., Desert sediments: ancient and modern: Geological Society Special Publication, 129-138.

Wadell, H., 1932, Volume, shape and roundness of rock particles. Journal of Geology, 40, 443-451.

Weltje, G.J., 2002, Quantitative analysis of detrital modes: statistically rigorous confidence regions in ternary diagrams and their use in sedimentary petrology: Earth Science Review, 57, 211-253.

Wang, X., Dong, Z., Zhang, J., Qu, J., Zhao, A., 2003, Grain size characteristics of dune sands in the central Taklimakan Sand Sea: Sedimentary Geology, 161, 1-14.

Manuscript received: June 19, 2008.

Corrected Manuscript received: August 21, 2008.

Manuscript accepted: September 3, 2008. 